\title{
Partial replacement of cement by plant solid waste ash in concrete Production
}

\author{
Okwadha G.D.O., PhD \\ Department of Civil \& Construction Engineering, The Technical University of Kenya, P.O. Box 52428-00200 \\ Nairobi, Kenya.
}

\begin{abstract}
Chemical analysis of saw dust ash (SDA), maize cob ash (MCA), and sugarcane bagasse ash (SCBA) was performed to verify their pozzolanic activity for use in concrete manufacture. The sum of $\mathrm{SiO}_{2}, \mathrm{Al}_{2} \mathrm{O}_{3}$ and $\mathrm{Fe}_{2} \mathrm{O}_{3}$ was $75.39 \%, 77.64 \%$, and $80.23 \%$ for SDA, MCA, and SCBA respectively, indicating pozzolanic activity. Cement replacement was done at 0\%, 5\%, 10\%, 15\%, 20\%, 25\%, and 30\% by weight of cement. Workability decreased as cement replacement increases, but increased as cement replacement increases for SCBA. Absorption and compressive strength of 150mmx150mmx150mm cubes cured for 7,14 and 28 days increased as cement replacement increases up to an optimum then decreased as a consequence of decreased formation of cementitious matrix. Optimum compressive strength was 26.30, 27.71, and $49.58 \mathrm{Nmm}^{-2}$ for SDA, MCA, and $S C B A$ respectively at 10\% SDA and MCA, and 25\% SCBA. The results have shown that the use of blended concrete can reduce environmental degradation attributed to disposal of plant wastes and raw materials mining for cement manufacture, and pollution from cement manufacturing process.
\end{abstract}

Keywords: Absorption, Compressive Strength, Concrete, Pozzolanic Cement, Workability

\section{Introduction}

Cement is one of the most important concrete making materials in the building and construction industry. However, high cost of cement and other construction materials, over exploitation of the natural resources, and environmental concerns have necessitated the search for alternative materials for the building and construction industry. The search for alternative cement replacement has led to the discovery of industrial byproducts and agricultural wastes with pozzolanic abilities capable of being used as cementitious materials in the manufacture of concrete. Substantive energy and cost savings can be made when these by-products and wastes are used as cement replacement $[1,2]$. Environmental degradation due to mining and dumping of large quantities of waste materials would be reduced. Some of agricultural waste materials under research include Saw dust ash (SDA), maize cob ash (MCA) and sugarcane bagasse ash (SCBA).Saw dust ash (SDA) as a potential cement replacement binder has been studied by several researchers for several years. Marthong, Raheem and Sulaiman, Obilade and Nahak and Dash [3,4,5,6] reported that the compaction factor and the compressive strength decreased with increased cement replacement. The optimum SDA cement replacement was $10 \%$.

Olafusi and Olutoge [7] determined the compressive strength of cubes of size $150 \mathrm{~mm} \times 150 \mathrm{~mm}$ x150 $\mathrm{mm}$ made from corn cob ash (CCA) or maize cob ash (MCA) as partial replacement for cement in concrete and found out that it will be sufficient for plain concrete works and non-load bearing structures since it will enhance waste to wealth initiative. However, if high strength concrete is desired, then it will take longer curing period to achieve the designed strength. Consequently, the use of superplasticizers will be required to enhance workability. Price et al. [8] reported that replacing a portion of ordinary portland cement (OPC) with up to $10 \%$ CCA or MCA increased the compressive strength, enhanced insulation performance and workability time.

Ganesan et al. [9] studied sugarcane bagasse ash (SCBA) and reported that the addition of SCBA as cement replacement provides additional improvements in strength and permeability. Since SCBA is finer than OPC, its presence in OPC leads to an increase in water uptake with subsequent increase in both initial and final setting times with accelerated hardening [9]. In addition, the pozzolanic activity of SCBA depends significantly on its particle size and fineness [10,11]. Compressive strength of the composite concrete increased as the amount of cement replacement increases up to an optimum of $20 \%$ cement replacement $[9,11,12,13]$.

Recycling materials that otherwise would be treated as waste can create endless sustainable construction opportunities [8]. The main objectives of this study are to determine the pozzolanic activity of these plant ashes, their respective compressive strengths, and the optimum cement replacement that gives maximum strength concrete that can enable such blended concretes to used in construction works to reduce environmental degradation associated with mining materials for cement manufacture. 


\subsection{Plant ashes}

\section{Materials and Methods}

Saw dust was obtained from a Joinery Workshop at Gikomba Market, Nairobi. Dry maize cobs were obtained from a farmer in Kamulu, Machakos. The saw dust and maize cobs were burnt separately in an open metallic drum to produce the saw dust ash (SDA) and maize cob ash (MCA). They were then ground using pestle and mortar. The sugarcane bagasse ash (SCBA) was obtained from Mumias Sugar Mill in Mumias, Kenya. The ashes were then sieved through a British standard (BS) $75 \mu \mathrm{m}$ sieve to remove impurities and larger particles.

\subsection{Materials}

Coarse aggregates were obtained from a hard stone quarry in Kayole, Nairobi, River sand was used as fine aggregates, and were obtained from a river in Mwala, Machakos, and ordinary Portland cement (OPC) was bought from a hardware store in Nairobi.

\subsection{Chemical composition of the plant ashes}

The chemical composition of the ashes was determined in the Technical University of Kenya Chemistry Department Laboratory, and in accordance with ASTM C 311 (Standard Test Methods for sampling and testing fly ash or natural pozzolans for use in Portland cement concrete) [14], and evaluated in accordance with ASTM C618 (Standard specifications for coal fly ash and raw or calcined natural pozzolan for use in concrete) [15].

\subsection{Fresh Concrete}

A mix proportion of 1:2:4 was used to manufacture concrete in accordance with BS 1881-109, 1983 (Method for making test beams from fresh concrete) [16] at a water cement (w/c) ratio of 0.5. Replacement of OPC by the plant ashes was done at $0 \%, 5 \%, 10 \%, 15 \%, 20 \%, 25 \%$, and $30 \%$ by weight of cement. Slump test was done in accordance with BS 1881-102, 1983: Method for determination of slump. Compaction factor (CF) was done in accordance with BS 1881-103, 1993: Method for determination of compacting factor [17].

\subsection{Casting and curing of concrete test cubes}

Concrete test cubes were casted in $150 \mathrm{~mm}$ x $150 \mathrm{~mm}$ x $150 \mathrm{~mm}$ cube steel moulds in accordance with BS 1881-108, 1983: Method for making test cubes from fresh concrete [18], and were cured for 7, 14 and 28 days, and in accordance with BS 1881-111, 1983: Method of normal curing of test specimens $\left(20{ }^{\circ} \mathrm{C}\right.$ method) [19].

\subsection{Hardened Concrete}

Water absorption test was carried out on hardened concrete after 28 days cure in accordance with BS 1881-122, 2011: Method for determination of water absorption [20]. Compressive strength tests were carried out at 7, 14, and 28 days, and in accordance with BS 1881-116, 1983: Method for determination of compressive strength of concrete cubes [21].

\subsection{Chemical Composition of the plant ashes}

\section{Results and discussion}

TABLE 1 shows the chemical composition of the plant ashes (SDA, MCA and SCBA). The results indicate that all have pozzolanic ability since, in terms of their chemical composition, the sum of $\mathrm{SiO}_{2}, \mathrm{Al}_{2} \mathrm{O}_{3}$ and $\mathrm{Fe}_{2} \mathrm{O}_{3}$ were $75.39 \%, 77.64 \%$, and $80.23 \%$ for SDA, MCA, and SCBA respectively. The American Society for Testing of Materials (ASTM) has defined pozzolana on the basis of chemical composition as a substance whose sum of $\mathrm{SiO}_{2}, \mathrm{Fe}_{2} \mathrm{O}_{3}$ and $\mathrm{Al}_{2} \mathrm{O}_{3}$ should be at least $70.0 \%$ for good binding properties (ASTM C618, 2003). However, the SCBA exhibited high pozzolanic strength as compared with SDA and MCA. 
Table 1: Chemical Composition of Plant ashes (SDA, MCA, and SCBA)

\begin{tabular}{|l|l|l|l|}
\hline \multirow{2}{*}{ Oxide } & \multicolumn{3}{|l|}{ Percentage Content (\%) } \\
\cline { 2 - 4 } & \multicolumn{3}{|l|}{} \\
\cline { 2 - 4 } & SDA & MCA & SCBA \\
\hline & & & \\
\hline $\mathrm{SiO}_{2}$ & 65.22 & 66.8 & 69.82 \\
\hline $\mathrm{Al}_{2} \mathrm{O}_{3}$ & 5.96 & 6.64 & 6.05 \\
\hline $\mathrm{Fe}_{2} \mathrm{O}_{3}$ & 4.21 & 3.2 & 4.35 \\
\hline $\mathrm{CaO}$ & 4.50 & 11.21 & 1.63 \\
\hline $\mathrm{MgO}$ & 5.60 & 4.31 & 0.95 \\
\hline $\mathrm{SO}$ & 0.46 & 1.55 & 1.84 \\
\hline $\mathrm{MnO}$ & 0.01 & 0.02 & 0.01 \\
\hline $\mathrm{Na}_{2} \mathrm{O}$ & 0.12 & 0.25 & 1.10 \\
\hline $\mathrm{K}_{2} \mathrm{O}$ & 0.15 & 6.41 & 4.96 \\
\hline $\mathrm{P}_{2} \mathrm{O}_{5}$ & 1.56 & 1.80 & 1.26 \\
\hline $\mathrm{LOI}$ & 4.41 & 6.21 & 10.32 \\
\hline
\end{tabular}

\subsection{Workability}

TABLE 2 shows Slump test and Compaction factor (CF) results for SDA, MCA, and SCBA at 0\%, 5\%, $10 \%, 15 \%, 20 \%, 25 \%$, and $30 \%$ cement replacement. The results indicate that the slump and compaction factor for SDA and MCA decreases with increase in cement replacement. This could be due to decreased formation of the cementitious matrix attributed to insufficient water for workability and hydration. However, slump and compaction factor for SCBA increased with increase in cement replacement. This could be due to high surface area of SCBA that required less water for wetting the cement particles as more cement is being replaced.

Table 2: Slump and Compaction Factor (CF) of fresh blended concrete

\begin{tabular}{|l|l|l|l|l|l|l|l|l|}
\hline \multirow{3}{*}{ Ash Type } & \multirow{2}{*}{ Parameter } & \multicolumn{6}{|l|}{ Cement Replacement (\%) } \\
\cline { 3 - 10 } & 0 & 5 & 10 & 15 & 20 & 25 & 30 \\
\hline SDA & Slump & 62.5 & 60.2 & 58.6 & 56.8 & 50.3 & 45.0 & 32.3 \\
\cline { 2 - 10 } & C.F & 0.97 & 0.92 & 0.91 & 0.90 & 0.88 & 0.86 & 0.84 \\
\hline \multirow{2}{*}{ MCA } & Slump & 71.2 & 68.3 & 65.2 & 63.1 & 59.2 & 55.0 & 46.0 \\
\cline { 2 - 9 } & C.F & 0.94 & 0.93 & 0.91 & 0.88 & 0.85 & 0.84 & 0.82 \\
\hline \multirow{2}{*}{ SCBA } & Slump & 70.2 & 172 & 195 & 213 & 220 & 229 & 233 \\
\cline { 2 - 9 } & C.F & 0.95 & 0.96 & 0.96 & 0.97 & 0.97 & 0.98 & 0.98 \\
\hline
\end{tabular}

\subsection{Water absorption}

TABLE 3 shows water absorption test results for $150 \mathrm{~mm}$ x $150 \mathrm{~mm}$ x $150 \mathrm{~mm}$ blended concrete cubes after 28 days curing period for all the three plant ashes. The results indicate that absorption increases as cement replacement increases for all the ash concretes. However, the rate of increase was lower for SCBA concrete. This could be due to formation of less pervious cementitious matrix caused by increased workability and hydration. In addition, absorption decreases for all blended concrete after $25 \%$ cement replacement (Fig. 1).

Table 3: Water absorption for $150 \mathrm{~mm} \times 150 \mathrm{mmx} 150 \mathrm{~mm}$ blended concrete test cubes after 28 days cure.

\begin{tabular}{|c|c|c|c|c|c|c|c|c|}
\hline \multirow[t]{2}{*}{ Ash Type } & \multirow[t]{2}{*}{ Parameter } & \multicolumn{7}{|c|}{ Cement Replacement (\%) } \\
\hline & & 0 & 5 & 10 & 15 & 20 & 25 & 30 \\
\hline \multirow[t]{4}{*}{ SDA } & Dry Wt. (gm) & 8265 & 8357 & 8230 & 8118 & 7995 & 7950 & 7900 \\
\hline & Wet Wt. (gm) & 8355 & 8452 & 8341 & 8239 & 8129 & 8108 & 8066 \\
\hline & Water Absorbed (gm) & 90.0 & 95.0 & 111.0 & 121.0 & 134.0 & 158.0 & 166.0 \\
\hline & Absorption (\%) & 1.09 & 1.14 & 1.35 & 1.49 & 1.68 & 1.99 & 2.10 \\
\hline \multirow[t]{4}{*}{ MCA } & Dry Wt. (gm) & 8260 & 8351 & 8225 & 8112 & 7990 & 7942 & 7897 \\
\hline & Wet Wt. (gm) & 8352 & 8449 & 8338 & 8236 & 8125 & 8100 & 8071 \\
\hline & Water Absorbed (gm) & 92.0 & 98.0 & 113.0 & 124.0 & 135.0 & 158.0 & 174.0 \\
\hline & Absorption (\%) & 1.11 & 1.17 & 1.37 & 1.53 & 1.69 & 1.99 & 2.20 \\
\hline \multirow[t]{4}{*}{ SCBA } & Dry Wt. (gm) & 8260 & 8337 & 8231 & 8100 & 7986 & 7941 & 7900 \\
\hline & Wet Wt. (gm) & 8343 & 8425 & 8343 & 8227 & 8126 & 8089 & 8051 \\
\hline & Water Absorbed (gm) & 83.0 & 88.0 & 112.0 & 127.0 & 140.0 & 148.0 & 151.0 \\
\hline & Absorption (\%) & 1.00 & 1.06 & 1.36 & 1.57 & 1.75 & 1.86 & 1.91 \\
\hline
\end{tabular}




\subsection{Compressive Strength}

TABLE 4 shows the compressive strength of concrete cubes measuring $150 \mathrm{~mm} \times 150 \mathrm{~mm} \times 150 \mathrm{~mm}$ after 7, 14, and 28 days curing period. The compressive strength increased as cement replacement increases up to an optimum at $10 \%$ for SDA and MCA, and $25 \%$ for SCBA. This could be due to decreased formation of the cementitious matrix attributed to insufficient water for workability and hydration. At 28-day curing period, the compressive strength increased to an optimum of $26.30 \mathrm{Nmm}^{-2}, 27.71 \mathrm{Nmm}^{-2}$, and $49.58 \mathrm{Nmm}^{-2}$ for SDA, MCA, and SCBA respectively at 10\% cement substitution for SDA and MCA, and 25\% cement substitution for SCBA (Fig. 2). This followed the trend of the pozzolanic activity of the ashes. In addition, the compressive strength of $10 \%$ SDA and MCA concrete is about the same as $0 \%$ cement replacement at 28-day curing period. The results also indicate that the composite concretes can attain the same order of strength as conventional concrete at longer curing periods.

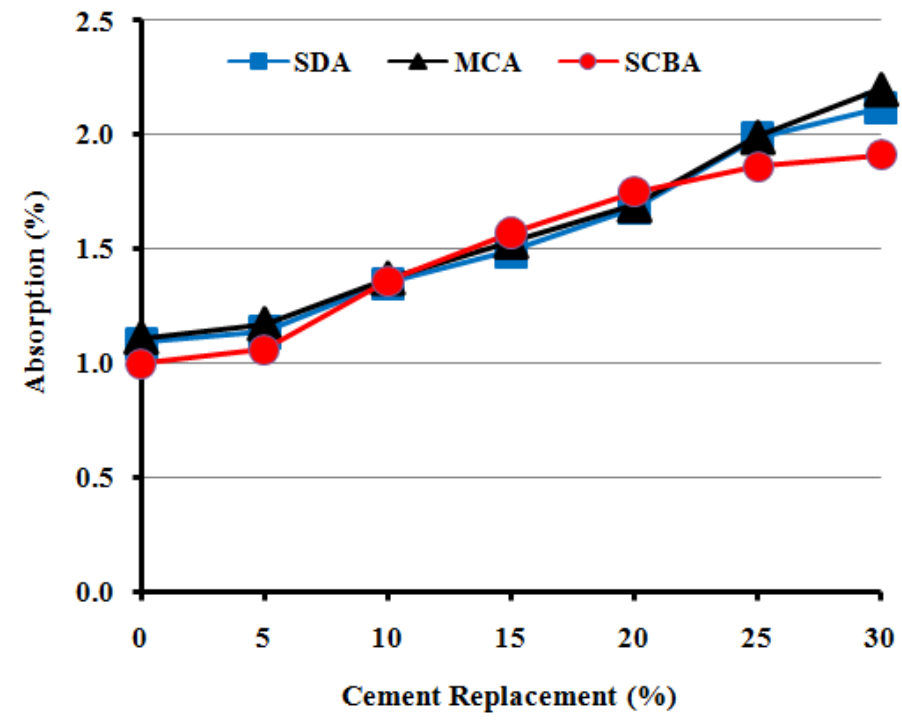

Fig. 1: Water absorption for $150 \mathrm{mmx} 150 \mathrm{mmx} 150 \mathrm{~mm}$ blended concrete test cubes after 28 days cure.

Table 4: Compressive Strength $\left(\mathrm{Nmm}^{-2}\right)$ for $150 \mathrm{~mm} \times 150 \mathrm{mmx} 150 \mathrm{~mm}$ blended concrete test cubes after 7, 14, and 28 days curing period.

\begin{tabular}{|l|l|l|l|l|l|l|l|l|}
\hline \multirow{2}{*}{ Ash Type } & Curing Period (Days) & \multicolumn{6}{l|}{ Cement Replacement (\%) } \\
\cline { 3 - 9 } & & 0 & 5 & 10 & 15 & 20 & 25 & 30 \\
\hline \multirow{3}{*}{ SDA } & 7 & 16.71 & 15.57 & 18.01 & 14.53 & 13.21 & 13.02 & 12.84 \\
\cline { 2 - 9 } & 14 & 22.65 & 18.91 & 21.88 & 15.01 & 14.95 & 14.76 & 14.53 \\
\cline { 2 - 9 } & 28 & 26.28 & 22.20 & 26.30 & 22.50 & 18.25 & 18.01 & 17.82 \\
\hline \multirow{3}{*}{ MCA } & 7 & 16.00 & 14.93 & 17.80 & 15.56 & 14.90 & 14.68 & 13.03 \\
\cline { 2 - 9 } & 14 & 22.57 & 19.78 & 23.02 & 23.00 & 22.81 & 20.54 & 15.23 \\
\cline { 2 - 8 } & 28 & 27.80 & 22.56 & 27.71 & 23.51 & 20.40 & 18.37 & 17.13 \\
\hline \multirow{3}{*}{ SCBA } & 7 & 30.04 & 25.42 & 34.00 & 35.93 & 36.01 & 36.21 & 35.25 \\
\cline { 2 - 8 } & 14 & 35.56 & 30.86 & 36.35 & 38.63 & 39.72 & 40.27 & 39.20 \\
\cline { 2 - 8 } & 28 & 48.90 & 42.50 & 44.50 & 46.45 & 47.23 & 49.58 & 48.65 \\
\hline
\end{tabular}




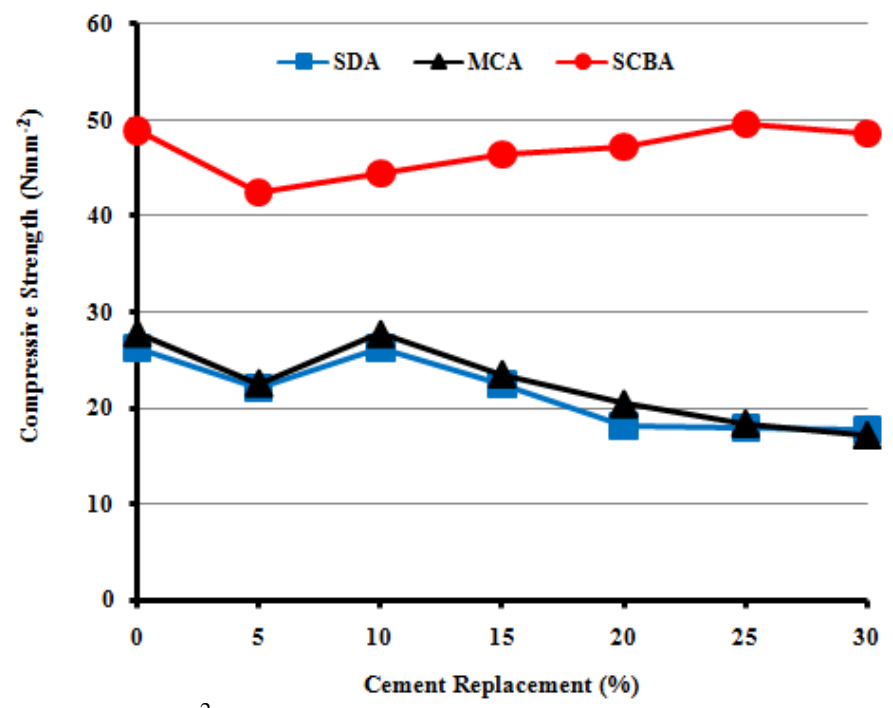

Fig. 2: Compressive Strength $\left(\mathrm{Nmm}^{-2}\right)$ for $150 \mathrm{~mm} \times 150 \mathrm{~mm} \times 150 \mathrm{~mm}$ blended concrete test cubes after 28 days curing period.

\section{Conclusions}

The following conclusions may be made from this study:

1. The SDA, MCA and SCBA have pozzolanic ability since, in terms of their chemical composition, the sum of $\mathrm{SiO}_{2}, \mathrm{Al}_{2} \mathrm{O}_{3}$ and $\mathrm{Fe}_{2} \mathrm{O}_{3}$ were $75.39 \%, 77.64 \%$, and $80.23 \%$ respectively. However, the SCBA shows high pozzolanic strength as compared with SDA and MCA.

2. Workability for SDA and MCA decreased with increase in cement replacement but increased as cement replacement increases for SCBA. This could be due to high surface area of SCBA that requires less water for wetting the cement particles as more cement is being replaced.

3. The compressive strength increased as cement replacement increases up to an optimum at $10 \%$ cement replacement for SDA and MCA, and $25 \%$ cement replacement for SCBA. This could be due to decreased formation of the cementitious matrix attributed to insufficient water for workability and hydration. At 28 day curing period, the compressive strength increased to an optimum of $26.30 \mathrm{Nmm}^{-2}, 27.71 \mathrm{Nmm}^{-2}$, and $49.58 \mathrm{Nmm}^{-2}$ for SDA, MCA, and SCBA respectively at $10 \%$ cement substitution for SDA and MCA, and $25 \%$ cement substitution for SCBA.

4. The compressive strength of $10 \%$ SDA and MCA concrete was about the same as that of $0 \%$ cement replacement at 28-day curing period. This indicates that blended concretes can attain the same order of strength as conventional concrete at longer curing periods.

5. The results have demonstrated that the use of plant ashes such as SDA, MCA, and SCBA as cement replacement should be encouraged for use in concrete to reduce environmental degradation associated with mining of cement manufacturing materials. This would also reduce construction budget associated with the high cost of cement since blended concrete of higher strength can be made with longer curing periods.

\section{Acknowledgements}

The authors are grateful to the Technical University of Kenya Departments of Civil and Construction Engineering and Chemistry for allowing them use their laboratories for this research.

\section{References}

[1]. M. Arikan, Feasibility Analysis of Manufacturing High Performance Ecological Cement in Turkey, Building and Environment, 39, 2004, 1125-1130.

[2]. L. Turanli, B. Uzal, F. Bektas,.Effect of Material Characteristics on the Properties of Blended Cements Containing High Volumes of Natural Pozzolans, Cem. Concr. Res. 34, 2004, 2277-2282.

[3]. . Marthong, Sawdust Ash (SDA) as Partial Replacement of Cement, Int. J. Eng. Res. Appl. 2, 2012, 1980-1985.

[4]. A. A. Raheem, O. K. Sulaiman, Saw Dust Ash as Partial Replacement for Cement in the Production of Sandcrete Hollow Blocks, Int. J. Eng. Res. Appl. 3, 2013, 713-721.

[5]. I. O. Obilade, Use of Saw Dust Ash as Partial Replacement for Cement in Concrete, J. Eng. Sci. Inv. 3, 2014, 36-40.

[6]. O. S. Olafusi, F. A. Olutoge, Strength Properties of Corn Cob Ash Concrete, J. Emerg. Trends Eng. Appl. Sci., 3, 2012, $297-301$.

[7]. A. Nahak, S. Dash, A Study on Strength of Concrete with Partial Replacement of Cement with Saw Dust Ash and Steel Fibre, Int. J. Eng. Res. Technol. 4, 2015, 134-137.

[8]. A. Price, R. Yeargin, E. Fini, T. Abu-Lebdeh, Investigating Effects of Introduction of Corncob Ash into Portland Cements Concrete: Mechanical and Thermal Properties, Am. J. Eng. Appl. Sci. 7, 2014, 137-148. 
[9]. K. Ganesan, K. Rajagopal, K. Thangavel Evaluation of bagasse ash as supplementary cementitious material, Cem. Concr. Compos. 29, 2007, 515-524.

[10]. G.C. Cordeiro, R.D. T. Filho, L.M. Tavares, E.M.R. Fairbairn, Pozzolanic activity and filler effect of sugar cane bagasse ash in Portland cement and lime mortars, Cem. Concr. Compos. 30, 2008, 410-418.

[11]. G.C. Cordeiro, R.D. T. Filho, L.M. Tavares, E.M.R. Fairbairn, Ultrafine grinding of sugar cane bagasse ash for application as pozzolanic admixture in concrete, Cem. Concr. Res. 39, 2009, 110-115.

[12]. N. Chusilp, C. Jaturapitakkul, K. Kiattikomol, Utilization of bagasse ash as a pozzolanic material in concrete, Constr. Build. Mater. 23, 2009, 3352-3358.

[13]. P. O. Modani, M. R.Vyawahare, Utilization of Bagasse Ash as a Partial Replacement of Fine Aggregate in Concrete, Proced. Eng. $51,2013,25-29$.

[14]. ASTM C311:02, Standard test methods for sampling and testing fly ash or natural pozzolans for use in Portland-cement concrete. American Society for Testing and Materials, 2002.

[15]. ASTM C618:03, Standard specification for coal fly ash and raw or calcined natural pozzolan for use in concrete. American Society for Testing and Materials, 2003.

[16]. BS 1881: Part 102, 1983: Methods for determination of slump. British Standard Institute, London, UK.

[17]. BS 1881: Part 103, 1993: Method for determination of compacting factor. British Standard Institute, London, UK.

[18]. BS 1881-108, 1983: Method for making test cubes from fresh concrete. British Standard Institute, London, UK

[19]. BS 1881: Part 111, 1983: Method of normal curing of test specimens ( $20^{\circ} \mathrm{C}$ method). British Standard Institute, London, UK.

[20]. BS 1881: Part 122, 2011: Method for determination of water absorption. British Standard Institute, London, UK.

[21]. BS 1881-116, 1983: Method for determination of compressive strength of concrete cubes. British Standard Institute, London, UK. 